\title{
Stock Market Reaction to Indonesia Presidential and Legislative Election
}

\author{
Erna Listyaningsih ${ }^{1 *}$; Eka Sariningsih ${ }^{2}$; Ritali Mudrikah ${ }^{3}$ \\ ${ }^{1-3}$ Department of Accounting, Faculty of Economics, Universitas Malahayati \\ Jln. Pramuka No.27, Bandar Lampung 35152, Indonesia \\ 1ernatya04@yahoo.com; ${ }^{2}$ ekasariningsih@yahoo.com; ${ }^{3}$ ritalievimudrikah@gmail.com
}

Received: 29 ${ }^{\text {th }}$ February 2020/ Revised: $31^{\text {st }}$ March 2020/ Accepted: $3^{\text {rd }}$ April 2020

How to Cite: Listyaningsih, E., Sariningsih, E., \& Mudrikah, R. (2020). Stock Market Reaction to Indonesia Presidential and Legislative Election. Binus Business Review, 11(2), 91-96. https://doi.org/10.21512/bbr.v11i2.6302

\begin{abstract}
The research investigated the reaction to Jakarta Islamic Index (JII) stocks around the Indonesia Presidential and Legislative Election in 2019. It was the first time that the election of the president and legislative assembly was held on the same day in Indonesia. The sample used was 30 stocks of JII. The event study methodology was conducted on this issue. The results show a significant positive abnormal return on the tenth day before the event and the seventh day after the event. From the liquidity, it is found that this event has a strong effect on Trading Volume Activity (TVA) of JII stocks surrounding the event. Additionally, another liquidity proxy, namely bid-ask spread, has the same result by experiencing a significant positive difference before and after the event. These results indicate that the information on the event is sufficient to influence the price, TVA, and size of the bid-ask spread of JII stock.
\end{abstract}

Keywords: stock market, Indonesia Presidential Election, Indonesia Legislative Election, Jakarta Islamic Index (JII)

\section{INTRODUCTION}

The research investigating the impact of the presidential election on the stock market is interesting to be explored. Additionally, the results of this impact on this issue are various. Previous researchers find that there are impacts of the presidential election on the stock market (Białkowski, Gottschalk, \& Wisniewski, 2008; Blau, Griffith, \& Whitby, 2019; Leblang \& Mukherjee, 2005; Ramesh, 2015).

In Indonesia, the presidential election affects stock market (Akbar, Saerang, \& Maramis, 2019; Mansur \& Jumaili, 2014; Manurung, 2019; Pamungkas, Suhadak, \& Endang, 2015; Sopyana \& Yasa, 2016; Purba \& Silalahi, 2017; Suwaryo, 2008). However, the other researchers find no effects of Indonesia presidential election on LQ45 stocks (Nugraha \& Suroto, 2019; Wahyu \& Lasmini, 2019; Suryani \& Rasmini, 2019). Additionally, the other suggests that there is a significant effect on stock liquidity, but it is not on stock return (Zulfitra \& Tumanggor, 2019).

In Indonesia, the election, held on April $17^{\text {th }}$, 2019, was the first simultaneous election. In addition to electing the president and vice president, the 2019 election was also a moment for the Indonesians to elect the members of the House of Representatives (Dewan Perwakilan Rakyat (DPR)), Regional House of Representatives (Dewan Perwakilan Rakyat Daerah (DPRD)), and Regional Representative Board (Dewan Perwakilan Daerah (DPD)). Therefore, this event is the first moment in the history of the Indonesia election, which becomes a special event not only for Indonesians but also for the Indonesia stock market.

Rika (2019) suggested that it could be seen that the Composite Stock Price Index (CSPI) had been through the level of 6.629 or risen to $0,92 \%$ from the opening position at the level of 6.568. In addition, when Jakarta Composite Index (JCI) was closing, the volume data showed an increase. On the third day before the Indonesia Presidential and Legislative Election, the closing prices were Rp6.405,866 with a volume of 1.689 . On the second day before the event, the closing prices were Rp6.435,151 with a volume of 1.427. Then, a day before the event, closing prices were Rp6.481,541 with a volume of 1.467. From these data, it showed an increase in closing prices ahead of election day. Then, it was strengthened on the first day after the event. The closing prices were Rp6.507,221 
with a volume of 1.546. Likewise, Budiawati (2019), using the Sharia indices such as Jakarta Islamic Index (JII) and Indonesia Sharia Stock Index (ISSI), indicated an increase in one day before and after the event. It suggested that the event was responded positively to the stock market.

The stock market reaction to the presidential election can be seen through the stock price movement by measuring abnormal return (Blau et al., 2019). If the event contains information, the investor will get an abnormal return. However, if the event does not provide any information, there will be no abnormal return obtained by investors (Jogiyanto, 2015).

In the context of Indonesia, the Indonesia Presidential and Legislative Election in 2019 is an event that contains new hopes for leaders in the future. The new hope can make the market react to the information in the event. The market reaction itself can be seen from the difference in abnormal returns around the event. This difference can be obtained by comparing the abnormal returns before and after the events of political events (Hutami \& Ardiyanto, 2015).

Furthermore, the stock market reaction to information can also be seen through the parameters of the movement of trading activities in the market (Pamungkas et al., 2015; Sihotang \& Mekel, 2015). Trading Volume Activity (TVA) is analyzed to see the reaction of the stock market to information through the parameters of the movement in the market. It is also to obtain a more comprehensive picture of the market reaction. If, after an event occurs, TVA increases, the information released is positive. On the contrary, if TVA decreases, the information published is negative (Mansur \& Jumaili, 2014). If investors interpret this information as a positive signal, the demand for stocks will be higher than the stock offering so that the TVA will increase.

Conversely, for a negative signal on information, the level of stock demand that occurs will be lower than the level of the stock offering. Thus, TVA will decrease (Mansur \& Jumaili, 2014; Sari, Purnamawati, \& Herawati, 2017). Therefore, Indonesia Presidential and Legislative Election in 2019 can emerge the reaction in the stock market by the change in TVA.

Another liquidity proxy is the bid-ask spread (Bohmann, Michayluk, Patel, \& Walsh, 2019). By using the bid-ask spread as a measure, the smaller the bid-ask spread of a stock is, the more liquid the stock will be (Mansur \& Jumaili, 2014; Prasiska \& Nuzula, 2018). It is to measure the liquidity in which there is no single measure to capture all facets of liquidity (Leirvik, Fiskerstrand, \& Fjellvikås, 2017). Therefore, the research conducts the analysis using two liquidity proxies.

Next, JII stocks are one of the most liquid indexes in the Indonesia Stock Exchange (IDX). Besides sharia compliance, it has high market capitalization and liquidity and lower volatility (Listyaningsih \& Krishnamurti, 2016). Therefore, researchers use JII stocks.

There are some differences between current research and previous research. First, the researchers explore the reaction of the Indonesia stock market comprehensively. Second, to measure the liquidity around the event, the researchers use TVA and Corwin and Schultz's bid-ask spread (Ripamonti, 2016). Third, the previous researchers conduct this issue on the LQ45 stocks and mining stocks. Meanwhile, the researchers use JII stocks. Although LQ45 stocks have the same characteristics from the liquidity perspective, Sharia stocks have other characteristics, such as low volatility.

In sum, the reaction to the stock market toward the presidential election and political events of previous research is still varying. It may be caused by the candidate of the president, whether the market can receive him or her or not. Therefore, the research is interesting to be explored further. The researchers examine the reaction for JII stocks around the Indonesia Presidential and Legislative Election in 2019.

\section{METHODS}

The research uses event study methodology to investigate the reaction of the stock market around the political event (Akbar et al., 2019; Blau et al., 2019; Diaraya et al., 2019; Wibowo \& Darmanto, 2019; Zulfitra \& Tumanggor, 2019). The research that study market reaction to an event with information published as an announcement is called event study (MacKinlay, 1997).

Next, the non-probability sampling technique is employed. This non-probability sampling technique is used by not providing equal opportunities in the sampled population. The technique used is a purposive sampling technique.

The data are JII stocks from November 2018 to April 2019. The data are daily prices of JII stocks, and the sample size is $30 \mathrm{JII}$ stocks. All data are retrieved from IDX.

To measure abnormal return, the researchers use Equation (1) from Jogiyanto (2015). AbRet ${ }^{i_{1}}$ is an abnormal return of the i security in the t-event period. $\mathrm{R}_{\mathrm{i}{ }^{\prime} \mathrm{t}}$ is the actual return that occurs to $\mathrm{i}$ securities in the $t$-event period, and $E\left[\mathrm{R}_{\mathrm{i}, \mathrm{t}}\right]$ is an expected return on $\mathrm{i}$-securities for the t-event period. The equation is as follows:

$$
\operatorname{AbRet}_{\mathrm{i}, \mathrm{t}}=\mathrm{R}_{\mathrm{i}, \mathrm{t}}-\mathrm{E}\left[\mathrm{R}_{\mathrm{i}, \mathrm{t}}\right]
$$

Next, to calculate Trading Volume Activity (TVA), the researchers adopt the equation used by Asmorojati, Diana, and Afifudin (2017). TVA ${ }_{i t}$ is a trading volume activity of $i$ securities on $t$-day, and $n$ is the number of securities. The equation can be seen as following:

$$
\mathrm{TVA}_{\mathrm{it}}=\frac{\sum_{i}^{n} \text { TVAit }}{n}
$$


To calculate bid-ask spread, Corwin and Schultz's bid-ask spread is applied (Corwin \& Schultz, 2012). Moreover, Listyaningsih and Krishnamurti (2016) and Ripamonti (2016) had used this equation in their research. Bid-ask spread denotes s, and exponential is e. To find out e, the researchers have to know $\alpha, \beta$, and $\gamma$ which can be calculated from daily high and low prices. Those are the sums of the expected squared ratio of high and low prices for two consecutive days. Then, $\gamma$ equals to a squared ratio of high and low prices in the range of two days. The equations are as follows:

$$
\begin{aligned}
& S=\frac{2\left(e^{\alpha}-1\right)}{1+e^{\alpha}} \\
& \alpha=\frac{\sqrt{2 \beta}-\sqrt{\beta}}{3-2 \sqrt{2}}-\sqrt{\frac{\gamma}{3-2 \sqrt{2}}} \\
& \beta=\sum_{j=1}^{1}\left[\ln \left(\frac{H_{t+1}^{0}}{L_{t+1}^{0}}\right)\right]^{2} \\
& \gamma=\left[\ln \left(\frac{H_{t, t+1}^{0}}{L_{t, t+1}^{0}}\right)\right]^{2}
\end{aligned}
$$

The data analysis technique is the normality test and t-test. The decision-making on this test is taken if the significance probability is $\alpha<0,05$. Then, Ho is rejected, which means that the data are not normally distributed. Additionally, if the significance probability is $\alpha>0,05$, Ho is accepted, or the data are normally distributed. Next, if the data are normally distributed, the analytical tool used is the parametric statistical t-test.

\section{RESULTS AND DISCUSSIONS}

The researchers investigate the reaction of the Indonesia Presidential and Legislative Election in 2019 on the stock market. The market reaction can be seen from the abnormal return and the liquidity perspective of the JII stocks in November 2018 to April 2019. Then, the results of the t-test of abnormal return (AbRet), TVA, and bid-ask spread of JII stocks are seen in Tables $1-6$.

Table 1 shows the abnormal return on the first day before the event experiences a negative but insignificant effect. By the second to the sixth day, it has a positive but insignificant effect. Then, on the seventh to the ninth day, it fluctuates.

On the tenth day before the event, it experiences a significant positive difference. Next, the first to the sixth day after the event, it has a positive but insignificant effect. Meanwhile, on the seventh day and the tenth day after the event, it experiences a significant difference, although it is negative on the tenth day. Due to the significant positive difference on the seventh day after the event, the event indicates having information content (Blau et al., 2019). The result is not supported by the previous research results in Indonesia, which investigate this issue on LQ45 stocks (Nugraha \& Suroto, 2019; Zulfitra \& Tumanggor, 2019). However, this finding is in line with Setiawan and Nisa (2020), who found that there was an abnormal return around the quick count of the election of the Indonesia President in 2019.

Table 1 One-Sample T-Test of JII AbRet

\begin{tabular}{cccr}
\hline No & Average AbRet & T-Statistic & P-Value \\
\hline 10. & 0,99447 & 345,389 & $* * * 0,000$ \\
9. & $-0,10615$ & 1,048 & 0,303 \\
8. & 0,00099 & 0,297 & 0,679 \\
7. & $-0,00051$ & $-0,155$ & 0,878 \\
6. & 0,00490 & 1,559 & 0,130 \\
5. & 0,00029 & 0,076 & 0,940 \\
4. & 0,00615 & 1,683 & 0,103 \\
3. & 0,00282 & 0,643 & 0,525 \\
2 & 0,00127 & 0,389 & 0,700 \\
1 & $-0,00275$ & $-0,872$ & 0,391 \\
& & Event & \\
1. & 0,00200 & 0,437 & 0,666 \\
2. & 0,00682 & 1,909 & 0,666 \\
3. & 0,00094 & 0,297 & 0,768 \\
4. & 0,00074 & 0,222 & 0,826 \\
5. & 0,00048 & 0,114 & 0,910 \\
6. & 0,00284 & 0,930 & 0,360 \\
7. & 0,00769 & 2,416 & $* * 0,022$ \\
8. & $-0,00403$ & $-0,787$ & 0,437 \\
9. & 0,00878 & $-2,019$ & 0,053 \\
10. & $-0,00473$ & $-1,601$ & $* * 012$ \\
\hline & & & \\
\hline
\end{tabular}

** Significant at 5\%

*** Significant at $1 \%$

Table 2 Paired Sample T-Test of JII AbRet

\begin{tabular}{ccccc}
\hline No & $\begin{array}{c}\text { Average } \\
\text { AbRet Before } \\
\text { Event }\end{array}$ & $\begin{array}{c}\text { Average } \\
\text { AbRet After } \\
\text { Event }\end{array}$ & T-Statistics & P-Value \\
\hline 1. & $-0,00275$ & 0,00200 & 1,695 & 0,101 \\
2. & 0,00127 & 0,00682 & $-0,005$ & 0,323 \\
3. & 0,00282 & 0,00094 & 0,67 & 0,508 \\
4. & 0,00615 & 0,00074 & 1,07 & 0,293 \\
5. & 0,00029 & 0,00048 & $-0,957$ & 0,347 \\
6. & 0,00490 & 0,00284 & $-0,432$ & 0,669 \\
7. & $-0,00051$ & 0,00769 & 0,913 & 0,369 \\
8. & 0,00099 & $-0,00403$ & 0,779 & 0,442 \\
9. & $-0,10615$ & 0,00878 & $-1,072$ & 0,293 \\
10. & 0,99447 & $-0,00473$ & 2,922 & $* * * 0,007$ \\
\hline
\end{tabular}

*** Significant at $1 \%$ 
Next, from Table 2, it can be seen that only on the tenth day after the event date, the abnormal return is significantly lower than the previous day. Although the first day is higher than the previous day, it is insignificant. On the first day and the second day, the stock market experiences higher abnormal return than the previous day, but it is insignificant. The finding is not supported by the results of Nugraha and Suroto (2019) and Zulfitra and Tumanggor (2019), who examined this issue in the LQ45 index.

Table 3 One-Sample T-Test of JII TVA

\begin{tabular}{|c|c|c|c|}
\hline No & Average TVA & T-Statistics & P-Value \\
\hline 10. & 0,00100 & 6,646 & $* * * 0,000$ \\
\hline 9. & 0,07108 & 1,033 & 0,310 \\
\hline 8. & 0,00157 & 5,446 & $* * * 0,000$ \\
\hline 7. & 0,00160 & 7,317 & $* * * 0,000$ \\
\hline 6. & 0,00160 & 7,329 & $* * * 0,000$ \\
\hline 5. & 0,00167 & 5,546 & $* * * 0,000$ \\
\hline 4. & 0,00114 & 7,814 & $* * * 0,000$ \\
\hline 3. & 0,00134 & 5,543 & $* * * 0,000$ \\
\hline 2 & 0,00160 & 5,006 & $* * * 0,000$ \\
\hline 1 & 0,00202 & 4,258 & $* * * 0,000$ \\
\hline \multicolumn{4}{|c|}{ Event } \\
\hline 1. & 0,00318 & 4,419 & $* * * 0,000$ \\
\hline 2. & 0,00137 & 5,614 & $* * * 0,000$ \\
\hline 3. & 0,00146 & 5,960 & $* * * 0,000$ \\
\hline 4. & 0,00135 & 5,408 & $* * * 0,000$ \\
\hline 5. & 0,00155 & 6,560 & $* * * 0,000$ \\
\hline 6. & 0,00133 & 4,348 & $* * * 0,000$ \\
\hline 7. & 0,00136 & 5,140 & $* * * 0,000$ \\
\hline 8. & 0,00189 & 4,631 & $* * * 0,000$ \\
\hline 9. & 0,00189 & 6,084 & $* * * 0,000$ \\
\hline 10. & 0,00192 & 6,286 & $* * * 0,000$ \\
\hline
\end{tabular}

*** Significant at $1 \%$

In Table 3, on the first day to the eighth day before the event, TVA has a significant positive difference. Additionally, on the first day to the tenth day after the event, TVA experiences a significant positive difference. It indicates that there is an increase in TVA surrounding the event. The results also suggest that after the event, TVA has a significant positive difference. It means that investors interpret this event as positive information (Mansur \& Jumaili, 2014). The result is supported by Nugraha and Suroto (2019) and Zulfitra and Tumanggor (2019).

From Table 4, only on the first day, TVA is significantly higher than the previous day. It indicates that many investors sell stocks on that day so that there is an increase in TVA. Then, it causes a difference in the average of TVA in JII. However, by the second day to the tenth day, the transaction of buying and selling surrounding the event is insignificant from the previous day. This result supports the research of
Akbar et al. (2019). They agreed that the event of the victory announcement also affected investors' trading activities with very small fluctuation on a daily basis. So, there was almost no visible existed reaction.

This finding is also supported by the previous researchers on LQ45 stocks such as Nugraha and Suroto (2019) and Zulfitra and Tumanggor (2019). However, the researchers find a different result that there is a positive difference between TVA before and after the event.

Table 4 Paired Sample T-Test of JII TVA

\begin{tabular}{ccccc}
\hline No & $\begin{array}{c}\text { Average } \\
\text { TVA Before } \\
\text { Event }\end{array}$ & $\begin{array}{c}\text { Average } \\
\text { TVA After } \\
\text { Event }\end{array}$ & T-Statistics & P-Value \\
\hline 1. & 0,00202 & 0,00318 & 2,922 & $* * * 0,007$ \\
2. & 0,00160 & 0,00137 & -1.072 & 0,293 \\
3. & 0,00134 & 0,00146 & 0,779 & 0,442 \\
4. & 0,00114 & 0,00135 & 0,913 & 0,369 \\
5. & 0,00167 & 0,00155 & -0.432 & 0,669 \\
6. & 0,00160 & 0,00133 & -0.957 & 0,347 \\
7. & 0,00160 & 0,00136 & 1,07 & 0,293 \\
8. & 0,00157 & 0,00189 & 0,670 & 0,508 \\
9. & 0,07108 & 0,00189 & $-0,005$ & 0,323 \\
10. & 0,00100 & 0,00192 & 1,695 & 0,101 \\
\hline
\end{tabular}

$* * *$ Significant at $1 \%$

Table 5 One-Sample T-Test of JII Bid-Ask Spread

\begin{tabular}{cccr}
\hline No & $\begin{array}{c}\text { Average Bid-Ask } \\
\text { Spread }\end{array}$ & T-statistics & P-Value \\
\hline 10. & 0,0358343 & 2,074 & $* * 0,047$ \\
9. & 0,0352141 & 1,888 & 0,069 \\
8. & 0,0355283 & 2,202 & $* * 0,036$ \\
7. & 0,0364826 & 2,506 & 0,018 \\
6. & 0,0330750 & 1,227 & 0,230 \\
5. & 0,0306013 & 0,271 & 0,789 \\
4. & 0,0314438 & 0,555 & 0,583 \\
3. & 0,0325378 & 0,849 & 0,403 \\
2 & 0,0325935 & 0,948 & 0,351 \\
1 & 0,0288400 & 0,347 & 0,731 \\
& & Event & \\
1. & 0,0405936 & 0,252 & 0,803 \\
2. & 0,0362158 & 0,072 & 0,943 \\
3. & 0,0340765 & $-40,395$ & $* * * 0,000$ \\
4. & 0,0340287 & 0,010 & 0,992 \\
5. & 0,0356536 & $-40,148$ & $* * * 0,000$ \\
6. & 0,0345364 & $-1,672$ & 0,094 \\
7. & 0,0346227 & $-45,618$ & $* * * 0,000$ \\
8. & 0,0420232 & $-40,643$ & $* * * 0,000$ \\
9. & 0,0467716 & $-0,066$ & 0,948 \\
10. & 0,0037550 & $-19,652$ & $* * * 0,000$ \\
\hline
\end{tabular}

*** Significant at $1 \%$

** Significant at 5\% 
In Table 5, on the eighth and the tenth day before the event, the bid-ask spread experiences a significant positive difference at the $5 \%$ level. Additionally, the third day, the fifth day, the seventh day, the ninth day, and the tenth day after the event, the bid-ask spread has a significant positive difference at the $1 \%$ level respectively. It indicates that this event affects TVA of JII stocks. This result is not supported by previous research on mining stocks (Mansur \& Jumaili, 2014).

Table 6 Paired Sample T-Test of JII Bid-Ask Spread

\begin{tabular}{ccccr}
\hline No & $\begin{array}{c}\text { Average Bid- } \\
\text { Ask Spread } \\
\text { Before Event }\end{array}$ & $\begin{array}{c}\text { Average Bid- } \\
\text { Ask Spread } \\
\text { After Event }\end{array}$ & T-Statistics & P-Value \\
\hline 1. & 0,02884 & 0,04059 & $-4,755$ & $* * * 0,000$ \\
2. & 0,03259 & 0,03622 & $-1,291$ & 0,207 \\
3. & 0,03254 & 0,03408 & 40,439 & $* * * 0,000$ \\
4. & 0,03144 & 0,03403 & $-0,800$ & 0,430 \\
5. & 0,03060 & 0,03565 & 40,130 & $* * * 0,000$ \\
6. & 0,03308 & 0,03454 & $-0,620$ & 0,540 \\
7. & 0,03648 & 0,03462 & 0,516 & 0,610 \\
8. & 0,03553 & 0,04202 & $-1,529$ & 0,137 \\
9. & 0,03521 & 0,04677 & $-3,207$ & $* * * 0,003$ \\
10. & 0,03583 & 0,00376 & 19,920 & $* * * 0,000$ \\
\hline
\end{tabular}

*** Significant at $1 \%$

Next, from Table 6, it can be seen that the first day, the third day, the fifth day, and the ninth day after the event, the bid-ask spread is significantly higher than the previous day. However, on the tenth day after the event, the bid-ask spread is significantly lower than the previous day. The seventh day and the tenth day have a lower bid-ask spread than the previous day, but on the seventh day, it is insignificant. It means that the investors wait for the Indonesia Presidential and Legislative Election results and conduct a transaction carefully. Therefore, there is a higher bid-ask spread. The finding is not in line with the previous research in Indonesia on mining stocks by Mansur and Jumaili (2014). In addition, compared to the previous research, there is an average bid-ask spread before the event, and it is bigger than the previous day in this research.

Based on t-tests for abnormal return, it shows that the event affects the price of JII. It is because, on the seventh day after the event, it has a positive abnormal return. In addition, from liquidity proxies, namely TVA and the bid-ask spread, they have the same result. There are effects of Indonesia Presidential and Legislative Election on the liquidity of JII stocks. This finding is supported by the previous research regarding this issue on LQ45 stocks and mining stocks (Nugraha \& Suroto, 2019; Zulfitra \& Tumanggor, 2019). However, the result is not in line with the previous research regarding the bid-ask spread by Mansur an Jumaili (2014).

Nevertheless, these results imply that the information held by the dealer about the events of
Indonesia Presidential and Legislative Election in 2019 is sufficient. It can influence the price, the TVA, and the size of the bid-ask spread of JII stock. These findings are in line with Akbar et al. (2019), Manurung (2019), and Zulfitra and Tumanggor (2019). These results also show that the liquidity by using two proxies, namely TVA and bid-ask spread, has the same conclusion. Bid-ask spread by using the equation of Corwin and Schultz has robust accuracy. Therefore, the results of the research are robust.

\section{CONCLUSIONS}

Based on the analysis it can be concluded that the research finds out that the event of the Indonesia Presidential and Legislative Election affects the Indonesia stock market. The seventh day after the event, an abnormal return of JII stocks experiences a significant positive difference. However, on the tenth day, the abnormal return of JII has a significant negative difference. It can be said that this event has a weak effect on the abnormal return of JII stocks. However, it has a strong effect on liquidity, in which TVA and bid-ask spread have a significant difference surrounding the event.

Additionally, only the first day after the event, TVA is significantly higher than the previous day. It indicates that investors wait to conduct transactions. From the liquidity, it is robust due to employing two liquidity proxies, which have the same conclusion. Therefore, this event has an effect on the Indonesia stock market. The research has not investigated the volatility of JII prices in the event yet. It is suggested the future researchers do so because JII stocks have low leverage. They can also measure the volatility of stocks surrounding the event.

\section{REFERENCES}

Akbar, E. P., Saerang, I. S., \& Maramis, J. B. (2019). Reaksi pasar modal terhadap pengumuman kemenangan Presiden Joko Widodo berdasarkan keputusan KPU pemilu periode 2019-2024 (Studi pada perusahaan BUMN yang terdaftar di BEI). JMBI UNSRAT: Jurnal Manajemen Bisnis dan Inovasi Universitas Sam Ratulangi, 6(2), 123-131.

Asmorojati, W., Diana, N., \& Afifudin, A. (2017). Reaksi investor terhadap pengumuman kebijakan tax amnesty pada tanggal 1 Juli 2016 (Evet study pada perusahaan LQ45 yang terdaftar di BEI). Jurnal Ilmiah Riset Akuntansi, 6, 27-41.

Białkowski, J., Gottschalk, K., \& Wisniewski, T. P. (2008). Stock market volatility around national elections. Journal of Banking \& Finance, 32(9), 1941-1953.

Blau, B. M., Griffith, T. G., \& Whitby, R. J. (2019). Information in stock prices: The case of the $2016 \mathrm{US}$ presidential election. Applied Economics, 51(40), 4385-4396.

Bohmann, M., Michayluk, D., Patel, V., \& Walsh, K. (2019). Liquidity and earnings in event studies: Does data 
granularity matter? Pacific-Basin Finance Journal, 54(April), 118-131.

Budiawati, D. A. (2019). Indeks Syariah menguat sambut pemilu 2019. Retrieved January 20 ${ }^{\text {th }}, 2020$ from https://www.dream.co.id/dinar/jelang-pemiluindeks-syariah-menguat-190416i.html

Corwin, S. A., \& Schultz, P. (2012). A simple way to estimate bid-ask spreads from daily high and low prices. The Journal of Finance, 67(2), 719-760.

Diaraya, Haryanto, L., Lawi, A., Amir, S., Navira, A., \& Raya, A. R. (2019). An analysis of Fama and French three factor model in market reaction to Indonesia presidential election in 2019. Journal of Physics: Conference Series, 1341(6), 1-13.

Hutami, R. N., \& Ardiyanto, M. D. (2015). Abnormal return dan trading volume activity sebelum dan setelah pemilihan umum presiden secara langsung 9 Juli 2014 (Studi kasus pada saham LQ45). Diponegoro Journal of Accounting, 4(2), 1-4.

Jogiyanto, H. (2015). Teori portofolio dan analisis investasi (10 ${ }^{\text {th }}$ ed.). Yogyakarta: BPFE.

Leblang, D., \& Mukherjee, B. (2005). Government partisanship, elections, and the stock market: Examining American and British stock returns, 1930-2000. American Journal of Political Science, 49(4), 780-802.

Leirvik, T., Fiskerstrand, S. R., \& Fjellvikås, A. B. (2017). Market liquidity and stock returns in the Norwegian stock market. Finance Research Letters, 21(May), 272-276.

Listyaningsih, E., \& Krishnamurti, C. (2016). How is the volatility of Jakarta Islamic Index stocks? Jurnal Bisnis dan Manajemen, 17(2), 109-122.

MacKinlay, A. C. (1997). Event studies in economics and finance. Journal of Economic Literature, 35(1), 1339.

Mansur, F., \& Jumaili, S. (2014). Reaksi pasar modal terhadap peristiwa pemilihan umum tahun 2014 pada perusahaan terdaftar di Bursa Efek Indonesia. Jurnal Penelitian Universitas Jambi Seri Humaniora, 16(2), 59-68.

Manurung, H. (2019). Pengaruh pemilu serentak terhadap return saham di Indonesia (Studi kasus saham LQ-45 di Bursa Efek Indonesia). Journal for Business and Entrepreneurship, 3(1), 12-28.

Nugraha, C. H. A., \& Suroto. (2019). Abnormal return and trading volume activity before and after presidential election 2019 (Study on LQ-45 stock on FebruaryJuly 2019). Media Ekonomi dan Manajemen, 34(2), 229-241.

Pamungkas, A., Suhadak, \& Endang, M. G. W. (2015). Pengaruh pemilu Presiden Indonesia tahun 2014 terhadap abnormal return dan trading volume activity (Studi pada perusahaan pada perusahaan yang tercatat sebagai anggota indeks Kompas100). Jurnal Administrasi Bisnis, 21(2), 1-9.

Prasiska, Y., \& Nuzula, N. F. (2018). Analisis abnormal return dan bid-ask spread sebelum dan sesudah stock split (Studi pada perusahaan go public di BEI tahun 2013-2017). Jurnal Administrasi Bisnis, 59(1), 61-67.
Purba, S., \& Silalahi, M. (2017). Dampak quick count pilpres 2014 terhadap harga kurs USD, abnormal return dan aktivitas volume perdagangan saham di BEI (Uji kasus pada saham yang terdaftar dalam kelompok perusahaan LQ-45). Jurnal Ilmiah Methonomi, 3(1), 134-142.

Ramesh, A. (2015). Return volatility around national elections: Evidence from India. Procedia-Social and Behavioral Sciences, 189(May) 163-168.

Rika, H. (2019). Euforia kemenangan sementara JokowiMa'ruf hijaukan IHSG. Retrieved December $17^{\text {th }}, 2019$ from https:/www.cnnindonesia.com/ ekonomi/20190418134939-92-387633/euforiakemenangan-sementara-jokowi-maruf-hijaukanihsg

Ripamonti, A. (2016). Corwin-Schultz bid-ask spread estimator in the Brazilian stock market. BARBrazilian Administration Review, 13(1), 76-97.

Sari, N. P. T. P., Purnamawati, I. G. A., \& Herawati, N. T. (2017). Analisis komparatif saham LQ45 sebelum dan sesudah pilpres Amerika Serikat 2016. JIMAT (Jurnal Ilmiah Mahasiswa Akuntansi) Undiksha, 7(1), 1-10.

Setiawan, R., \& Nisa, Z. I. (2020). Reaksi pasar terhadap hasil quick count pemilu Presiden Indonesia 2019. Jurnal Ilmiah MEA (Manajemen, Ekonomi, \& Akuntansi), 4(1), 288-296.

Sihotang, E. M., \& Mekel, P. A. (2015). Reaksi pasar modal terhadap pemilihan umum Presiden tanggal 9 Juli 2014 di Indonesia. Jurnal EMBA: Jurnal Riset Ekonomi, Manajemen, Bisnis dan Akuntansi, 3(1), 951-960.

Sopyana, N. P. L., \& Yasa, G. W. (2016). Perbedaan reaksi pasar modal terhadap peristiwa pemilihan Presiden dan Wakil Presiden Republik Indonesia tahun 2014. Jurnal Buletin Studi Ekonomi, 21(2),136-146.

Suryani, N. N. W., \& Rasmini, N. K. (2019). Analisis reaksi pasar atas peristiwa pilkada serentak tahun 2018. E-Jurnal Akuntansi Universitas Udayana, 27(2), 1171-1201.

Suwaryo, S. (2008). Dampak pemilu Presiden dan Wakil Presiden terhadap abnormal return investor. Performance: Jurnal Personalia, Financial, Operasional, Marketing dan Sistem Informasi, 7(2), 1-19.

Wahyu, I. W. G., \& Lasmini, N. N. (2019). Reaksi pasar modal Indonesia terhadap penyelenggaraan pemilihan umum serentak 2019 di Indonesia. In Seminar Ilmiah Nasional Teknologi, Sains, dan Sosial Humaniora (SINTESA) (Vol. 2, No. 1).

Wibowo, A., \& Darmanto, S. (2019). Impact of quick count result of president election on stock prices and trade activities in the Indonesian capital market. Saudi Journal of Business and Management Studies, 4(6), 487-493.

Zulfitra, Z., \& Tumanggor, M. (2019). Pemilu serentak 2019 di Indonesia memberikan pengaruh terhadap likuiditas saham return saham dan harga saham LQ45 dibursa efek Indonesia. Jurnal Ekonomi Efektif, 2(1), 145-152. 